\title{
Disinhibisi Online sebagai Mediator Hubungan antara Kebingungan Identitas dan Cyberbullying pada Remaja
}

\section{Online Disinhibition as a Mediator of the Relationship between Identity Confusion and Cyberbullying in Adolescents}

\author{
Fadjri Kirana Anggarani, Fitri Amalia \\ Program Studi Psikologi Fakultas Kedokteran Universitas Sebelas Maret, Surakarta, \\ Indonesia
}

\begin{abstract}
Cyberbullying behavior utilized the use of digital technology and the internet as a medium for bullying. The purpose of this study was to examine the function of online disinhibition as a mediator of the relationship between identity confusion and cyberbullying in adolescents. Participants in the study were 12 to 15 years old or adolescents, which consisted of 151 men and 196 women. Data collection was performed using 3 scales namely the Cyberbullying Behavior Scale, the identity confusion scale, and the online disinhibition scale. The data obtained were tested using regression analysis with mediator variable with the help of IBM SPSS Statistics 21.0. The results showed that there was an effect of online disinhibition mediation on the relationship of identity confusion with cyberbullying. The result of MacKinnon analysis shows that the direct effect gives a bigger effect than the indirect effect.The results of the additional analysis show that males do more cyberbullying behavior; the higher the duration of internet and social media use, the more cyberbullying behavior that will be carried out by adolescents. These results indicated that adolescents and cyberbullying have many factors that required further research.
\end{abstract}

Keywords: Cyberbullying, online disinhibition, identity confusion, adolescents

\begin{abstract}
Abstrak: Perilaku cyberbullying memanfaatkan penggunaan teknologi digital dan internet sebagai media untuk melakukan aksi bullying. Tujuan dari penelitian ini adalah untuk menguji fungsi disinhibisi online sebagai mediator hubungan antara kebingungan identitas dan cyberbullying pada remaja. Partisipan dalam penelitian berusia 12 sampai dengan 15 tahun atau remaja yang terdiri dari 151 laki-laki dan 196 perempuan. Pengumpulan data dilakukan menggunakan 3 skala yaitu Skala Perilaku Cyberbullying, Skala kebingungan identitas, dan Skala disinhibisi online. Data yang diperoleh diuji menggunakan analisis regresi dengan melibatkan variabel mediator dengan bantuan IBM SPSS Statistics 21.0. Hasil penelitian menunjukkan bahwa ada pengaruh mediasi disinhibisi online pada hubungan kebingungan identitas dengan cyberbullying. Perhitungan peranan menggunakan MacKinnon diperoleh hasil bahwa efek langsung memberikan peran lebih besar dibandingkan efek tidak langsung. Hasil analisis tambahan menunjukkan bahwa laki-laki lebih banyak melakukan perilaku cyberbullying; semakin tinggi durasi penggunaan internet dan sosial media semakin banyak pula perilaku cyberbullying yang akan dilakukan remaja. Hasil ini menunjukkan bahwa remaja dan cyberbullying memiliki banyak faktor yang memerlukan penelitian lanjutan.
\end{abstract}

Kata kunci: Cyberbullying, disinhibisi online, kebingungan identitas, remaja

Korespondensi tentang artikel ini dapat dapat ditujukan pada Fadjri Kirana Anggarani melalui e-mail: fadjri.kirana@staff.uns.ac.id 
Perilaku cyberbullying pada remaja di Indonesia menjadi fenomena yang tidak asing lagi. Survei yang dilakukan Ipsos (2011) pada orang tua di 24 negara menunjukan Indonesia menduduki posisi kedua atas pengakuan orang tua bahwa anak di lingkungan tempat mereka tinggal memiliki pengalaman cyberbullying (53\%). Namun, $58 \%$ remaja di Indonesia tidak menyadari adanya cyberbullying baik sebagai pelaku maupun korban (Gayatri et al., 2015; The Jakarta Post, 2016). Perbedaan mendasar dari perilaku cyberbullying dengan perilaku bullying umumnya terletak pada penggunaan teknologi digital dan internet sebagai media untuk melakukan aksi bullying (Patchin \& Hinduja, 2010).

Adanya penggunaan teknologi digital dan internet, menjadikan perilaku cyberbullying dapat dilakukan secara anonim tanpa melihat respon atau dampak yang dimunculkan dari orang lain secara langsung. Karakteristik anonimitas ini erat kaitannya dengan disinhibisi online. Adanya jarak antara individu dengan lawan bicara kerap menghantarkan remaja untuk merasakan kondisi terbebas dari halangan sehingga dapat berkata atau melakukan halhal yang berbahaya ketika sedang online (Chadwick, 2014).

Tidak adanya informasi atas identitas pengguna (anonimitas) menimbulkan perasaan lebih terbebas dari tanggung jawab atas terhadap perilaku (Ching, Wu, \& Shih, 2017; Hu, Kumar, Huang, \& Ratnavelu, 2017). Disinhibisi online memungkinkan beberapa karakteristik psikologis dalam penggunaan internet menjadi berbeda ketika berada di dunia maya. Anonimitas dalam keadaan online mampu mengarahkan pada kehilangan kontrol sosial sehingga memicu perilaku cyberbullying (Görzig \& Ólafsson, 2014). Li (2007) menyebutkan bahwa salah satu faktor terpenting yang memengaruhi perilaku cyberbullying, yaitu karena adanya anonimitas di dunia maya. Adanya kesempatan menyembunyikan identitas dalam dunia maya, pelaku cyberbullying dapat mengintimidasi korban sepanjang hari dan sulit untuk dicegah.

Anonimitas yang terdapat dalam komunikasi elektronik tidak hanya berfungsi untuk menyamarkan identitas, tetapi dapat mengurangi konsep etika sosial, sehingga memudahkan pengguna untuk terlibat dalam tindakan agresif seperti cyberbullying (Li, 2007). Penelitian yang dilakukan pada 887 remaja di Jepang menunjukkan bahwa remaja dengan skor skala online disinhibition yang tinggi memungkinkan 1,2 kali lipat untuk melakukan cyberbullying (Udris, 2014). Penelitian lanjutan menunjukkan bahwa, online disinhibition merupakan prediktor terkuat bagi munculnya perilaku menyimpang ketika berada di dunia maya (Udris, 2017).

Disinhibisi online terjadi karena terdapat beberapa karakteristik psikologis dalam penggunaan internet yang mendukung seseorang untuk menjadi berbeda ketika berada di dunia maya. Karakteristik ini merujuk pada kurangnya pemahaman mengenai siapa dirinya dan apa peranannya di tatanan sosial yang lebih besar, yang kemudian disebut sebagai kebingungan identitas (identitiy confusion), dan sangat rentan pada remaja (Erikson, 1968).

Remaja yang mengalami kebingungan identitas akan mengembangkan mekanisme representasi diri yang tidak sehat, bertujuan untuk memperkecil konflik dalam diri mengenai perbedaan antara true self dengan ideal self mereka (Dayton, 2011; Schwartz, Zamboanga, Weisskirch, \& Rodriguez, 2009). Mekanisme ini mempengaruhi cara remaja merepresentasikan diri secara online (Gil-Or, Levi-Belz, \& Turel, 2015).

Kebingungan identitas merupakan kondisi negatif dari tercapainya identitas diri pada remaja. Remaja yang berada pada kondisi tersebut ditandai dengan karakteristik perilaku yang kacau dan perasaan rendah diri yang menyakitkan (Papalia, Olds, \& Feldman, 2009). Ketika remaja semakin berhasil mencapai identitas diri, maka semakin sehat kepribadiannya, namun apabila remaja tidak berhasil mencapai identitas diri pada masa krisis tersebut, maka akan 
mengalami kebingungan identitas (King, 2016).

Apabila remaja dengan kebingungan identitas tidak mendapatkan penanganan dengan baik, maka akan memunculkan persoalan mental yang menjadi dasar bagi remaja untuk melakukan perilaku delinkuen seperti tidak toleran, menjadi kejam ketika mengucilkan orang lain, dan bahkan perilaku kriminal (Erikson, 1968). Berdasarkan keseluruhan penjelasan di atas, maka penelitian menarik hipotesis: Disinhibisi online memediasi hubungan antara kebingungan odentitas dan cyberbullying.

\section{Metode}

\section{Partisipan}

Penelitian dilakukan di enam Sekolah Menengah Pertama (SMP) baik Swasta maupun Negeri dari enam kecamatan di Jakarta Selatan. Jumlah total partisipan dari keenam sekolah tersebut adalah 347 orang. Teknik pengambilan sampel (sampling) dilakukan dengan menggunakan multistage random sampling, yaitu teknik penarikan sampel melalui stratifikasi yang dipilih secara acak (Morissan, 2012).
Partisipan dalam penelitian berusia 12 sampai dengan 15 tahun atau remaja ( $M=$ 12.95, SD = 0.80), berasal dari dua kelas pada masing-masing sekolah. Jumlah subjek penelitian yang terinklusi adalah 347 orang, yang terdiri dari 151 laki-laki dan 196 perempuan. Sebagian besar responden (74.64\%) menggunakan media sosial selama lebih dari sama dengan 3 jam sehari ( $\geqq$ 3 jam sehari) dan menggunakan internet sebagian besar $(87.03 \%)$ setiap hari. Secara lebih rinci, data deskriptif partisipan penelitian dapat dilihat pada Tabel 1 .

\section{Pengumpulan Data}

Pengumpulan data dilakukan menggunakan 3 skala yaitu: (1) Skala perilaku cyberbullying (19 item, $\alpha$ sebesar 0.870), adaptasi skala yang disusun oleh Hinduja dan Patchin (2016); (2) Skala kebingungan identitas (18 item, $\alpha$ sebesar 0.889), disusun berdasarkan teori Erikson (1968); (3) Skala disinhibisi online (30 item, $\alpha$ sebesar 0.914), adaptasi skala yang disusun oleh Cheung, Wong dan Chan (2016) berdasarkan rumusan dimensi yang dikemukakan oleh Suler (2004a; 2004b).

Tabel 1. Analisis Deskriptif Data Demografis Subjek Penelitian (N=347)

\begin{tabular}{lcc}
\hline \multicolumn{1}{c}{ Karakteristik } & $\mathrm{N}$ & $(\%)$ \\
\hline Jenis Kelamin & & \\
$\quad$ Laki-laki & 151 & 43.52 \\
Perempuan & 196 & 56.48 \\
Usia & & \\
12 tahun & 113 & 32.6 \\
13 tahun & 142 & 40.9 \\
14 tahun & 86 & 24.8 \\
15 tahun & 6 & 1.7 \\
Durasi Penggunaan Media Sosial & & \\
Kurang dari 1 jam & 20 & 5.76 \\
1-2 jam sehari & 68 & 19.60 \\
3-4 jam sehari & 90 & 25.94 \\
Lebih dari 4 jam sehari & 169 & 48.70 \\
Frekuensi Penggunaan Internet & & \\
Jarang (kurang dari 1 hari seminggu) & 10 & 2.88 \\
1-3 hari seminggu & 17 & 4.90 \\
4-6 hari seminggu & 18 & 5.19 \\
Setiap hari & 302 & 87.03 \\
\hline
\end{tabular}


Tabel 2. Hasil Analisis Regresi

\begin{tabular}{|c|c|c|c|c|c|}
\hline Jalur & B (unstd) & SE & Sig. & $\alpha$ & $1-\beta$ \\
\hline $\begin{array}{l}\text { Efek Langsung Kebingungan Identitas > } \\
\text { Cyberbullying (Jalur-c) }\end{array}$ & 0,20 & 0,05 & 0,001 & 0,05 & 0,807 \\
\hline $\begin{array}{l}\text { Efek Kebingungan Identitas > Disinhibisi } \\
\text { Online (Jalur-a) }\end{array}$ & 0,36 & 0,10 & 0,001 & 0,05 & 0,802 \\
\hline $\begin{array}{l}\text { Efek Disinhibisi Online }>\text { Cyberbullying } \\
\text { (Jalur-b) }\end{array}$ & 0,13 & 0,02 & 0,001 & 0,05 & 0,804 \\
\hline $\begin{array}{l}\text { Efek Tidak Langsung Kebingungan } \\
\text { Identitas > Cyberbullying, mengontrol } \\
\text { Disinhibisi Online (Jalur-c') }\end{array}$ & 0,16 & 0,05 & 0,005 & 0,05 & 0,804 \\
\hline
\end{tabular}

Skala perilaku cyberbullying merupakan skala model Likert yang terdiri dari empat (4) pilihan jawaban: sering kali (SK), beberapa kali (BK), sesekali (S), dan tidak pernah (TP). Sedangkan skala kebingungan identitas dan skala disinhibisi online memiliki empat pilihan jawaban yaitu sangat sesuai (SS), sesuai (S), tidak sesuai (TS), dan sangat tidak sesuai (STS).

\section{Analisis Data}

Hipotesis penelitian ini diuji menggunakan analisis regresi dengan melibatkan variabel mediator yang menggunakan prosedur Baron dan Kenney (1998) dengan bantuan IBM SPSS Statistics 21.0.

\section{Hasil}

Hasil analisis menunjukkan bahwa kebingungan identitas dapat berpengaruh langsung ke cyberbullying dan dapat juga berpengaruh tidak langsung yaitu dari kebingungan identitas ke disinhibisi online (sebagai mediator) lalu ke perilaku cyberbullying. Besarnya pengaruh langsung (direct effect) adalah 0,1 sedangkan pengaruh tidak langsung (indirect effect) harus dihitung dengan mengalikan koefisien tidak langsung yaitu 0,047. Gambar 1 menunjukkan model regresi dengan mediator yang digunakan sebagai dasar prosedur analisis yang dilakukan. Hasil analisis menggunakan regresi dapat dilihat pada Tabel 2, Tabel 3, dan Tabel 4.
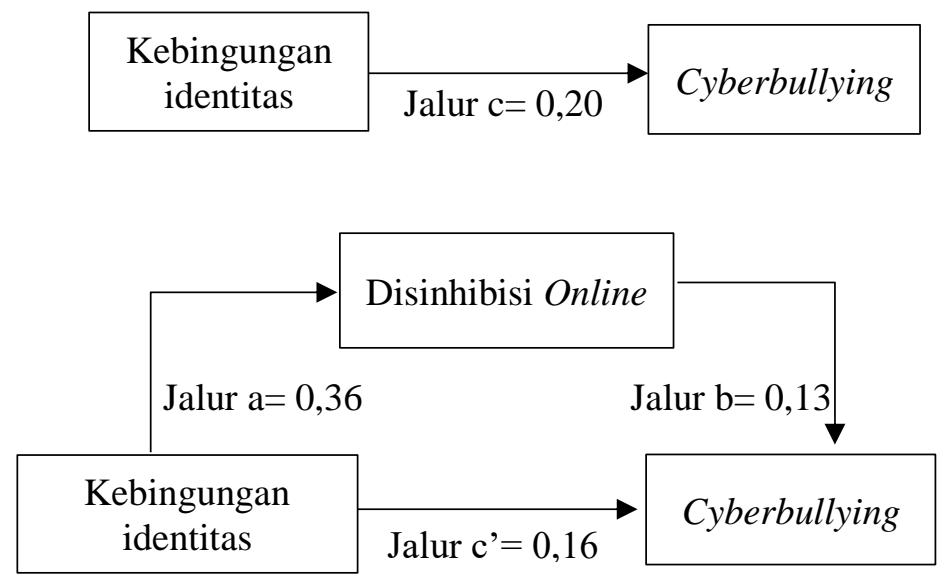

Gambar 1 Model Regresi dengan Mediator 
Tabel 3. Matriks Korelasi antar Variabel

\begin{tabular}{lccc|}
\hline & Kebingungan Identitas & Disinhibisi Online & Cyberbullying \\
\hline Kebingungan Identitas & 1 & & \\
Disinhibisi Online & $0,183^{* *}$ & 1 & \\
Cyberbullying & $0,184^{* *}$ & $0,229^{* *}$ & 1 \\
\hline
\end{tabular}

Tabel 4. Rangkuman Peranan Efek

\begin{tabular}{lcc}
\hline & Jalur & Koefisien \\
\hline Efek Tidak Langsung & Jalur ab & $0,36 \times 0,13=0,047$ \\
Efek Langsung & Jalur c & 0,16 \\
Efek Total & Jalur ab + Jalur c' & $0,047+0,16=0,207$ \\
\hline
\end{tabular}

Nilai B pada jalur a adalah 0,36 dan jalur b adalah 0,127 signifikan ( $\operatorname{sig}<0,05)$, maka dapat disimpulkan bahwa terdapat pengaruh mediasi disinhibisi online pada hubungan antara kebingungan identitas dengan cyberbullying. Mediator disinhibisi online merupakan mediator tidak sempurna karena hasil analisis jalur c' menunjukkan nilai $\mathrm{B}=0,16$ ( $\mathrm{sig}<0,05)$. Selanjutnya, diperlukan perhitungan analisis lanjutan untuk mengetahui efek langsung dan tidak langsung serta efek total berdasarkan informasi analisis regresi.

Berdasarkan hasil analisis di atas dapat diketahui bahwa efek langsung memiliki peranan lebih besar dibandingkan efek tidak langsung, dengan total peranan sebesar 0,207. Selanjutnya, diperlukan perhitungan besaran relatif melalui koefisien $\mathrm{P}_{\mathrm{M}}$ MacKinnon (Widhiarso, 2012), yang memperoleh hasil sebagai berikut:

\section{Proporsi Peranan Tidak Langsung}

$P_{M}=\frac{a b}{a b+c^{\prime}}=\frac{0,047}{0,207}=0,227$

Berdasarkan hasil di atas diperoleh bahwa efek tidak langsung dalam efek total adalah 22,7 persen.

\section{Proporsi Peranan Langsung}

$$
1-P_{M}=1-\frac{0,047}{0,207}=0,773
$$

Berdasarkan hasil di atas diperoleh bahwa efek langsung dalam efek total adalah
77,3 persen. Hasil analisis perhitungan besaran relatif menunjukkan bahwa efek langsung kebingungan identitas terhadap cyberbullying memiliki peranan yang lebih besar di dalam efek total pada hubungan mediasi dibandingkan efek tidak langsung yang melalui mediator disinhibisi online.

Hasil analisis deskriptif subjek pada Tabel 1 memperoleh hasil mengenai jenis kelamin, durasi penggunaan internet, dan intensitas penggunaan sosial media. Data ini kemudian dapat dijadikan sumber analisis tambahan.

\section{Perbedaan Perilaku Cyberbullying ditinjau dari Jenis Kelamin}

Perbedaan perilaku cyberbullying berdasarkan jenis kelamin diuji menggunakan independent sample T-test (lihat Tabel 5). Berdasarkan data, kedua kelompok gender memiliki varians skor yang sama (equal variances assumed) karena nilai signifikansi sebesar $0,925(\mathrm{p}>0,05)$. Hal tersebut menunjukkan bahwa data perilaku cyberbullying berdasarkan perbedaan jenis kelamin merupakan data yang homogen. Berdasarkan hasil analisis diperoleh hasil bahwa tidak terdapat perbedaan perilaku cyberbullying antara laki-laki dengan perempuan ( $\mathrm{t}-1,648$; sig > 0,05). Data juga menunjukkan bahwa perempuan melakukan perilaku cyberbullying lebih sering dibandingkan lakilaki (M Difference $=-1,044$ ). 
F. K. Anggarani \& F. Amalia: Disinhibisi Online sebagai Mediator Hubungan ... (116-127)

Tabel 5. Perbedaan Perilaku Cyberbullying ditinjau dari Jenis Kelamin

\begin{tabular}{|c|c|c|c|c|c|c|c|c|}
\hline \multirow{3}{*}{ Gender } & \multicolumn{3}{|c|}{ Cyberbullying } & $\mathrm{N}$ & M & \multicolumn{2}{|c|}{ Std. Dev. } & Std. Error M \\
\hline & \multicolumn{3}{|c|}{ Laki-Laki } & 151 & 5,497 & \multicolumn{2}{|c|}{$\overline{5,973}$} & 0,486 \\
\hline & \multicolumn{3}{|c|}{ Perempuan } & 195 & 6,564 & \multicolumn{2}{|c|}{5,764} & 0,413 \\
\hline & & \multirow{2}{*}{\multicolumn{2}{|c|}{$\begin{array}{c}\text { Levene's Test for } \\
\text { Equality of } \\
\text { Variances }\end{array}$}} & \multirow{2}{*}{\multicolumn{5}{|c|}{ t-test for Equality of Means }} \\
\hline & & & & & & & & \\
\hline & & $\mathrm{F}$ & Sig. & $\mathrm{t}$ & $\mathrm{df}$ & $\begin{array}{l}\text { Sig. (2- } \\
\text { tailed) }\end{array}$ & $\begin{array}{l}\text { Mean } \\
\text { Diff. }\end{array}$ & $\begin{array}{c}\text { Std. Error } \\
\text { Diff. }\end{array}$ \\
\hline Gender & $\begin{array}{l}\text { Equal } \\
\text { variances } \\
\text { assumed }\end{array}$ & 0,010 & 0,925 & $-1,648$ & 345 & 0,100 & $-1,044$ & 0,634 \\
\hline
\end{tabular}

Tabel 6. Perbedaan Cyberbullying ditinjau dari Frekuensi Penggunaan Internet

\begin{tabular}{|c|c|c|c|c|c|}
\hline \multicolumn{2}{|c|}{ Penggunaan Internet } & Mean & \multicolumn{2}{|c|}{ Std. Deviation } & $\mathrm{N}$ \\
\hline \multicolumn{2}{|c|}{ Jarang (kurang dari 1 kali seminggu) } & 1,700 & \multicolumn{2}{|c|}{1,829} & 10 \\
\hline \multicolumn{2}{|c|}{$1-3$ kali seminggu } & 3,470 & \multicolumn{2}{|c|}{2,125} & 17 \\
\hline \multicolumn{2}{|l|}{ 4-6 kali seminggu } & 4,500 & \multicolumn{2}{|c|}{5,148} & 18 \\
\hline \multicolumn{2}{|l|}{ Setiap hari } & 6,473 & \multicolumn{2}{|c|}{6,034} & 302 \\
\hline \multicolumn{2}{|l|}{ Total } & 6,087 & \multicolumn{2}{|c|}{5,867} & 347 \\
\hline Source & df & Mean Square & $\mathrm{F}$ & Sig. & $\begin{array}{c}\text { Partial Eta } \\
\text { Squared }\end{array}$ \\
\hline Penggunaan Internet & 3 & 133,094 & 3,966 & $0,008^{*}$ & 0,034 \\
\hline Error & 343 & 33,563 & & & \\
\hline
\end{tabular}

a. $\quad$ R Squared $=, 034$ (Adjusted R Squared $=, 025$ )

b. Dependent Variable: Cyberbullying

Tabel 7. Hasil Pairwise Perbedaan Cyberbullying ditinjau dari Frekuensi Penggunaan Internet Dependent Variable: Cyberbullying

\begin{tabular}{llccc}
\hline (I) Penggunaan Internet & (J) Penggunaan Internet & M Diff. (I-J) & Std. Error & Sig. $^{\text {b }}$ \\
\hline \multirow{3}{*}{ 1-3 kali seminggu } & 4-6 kali seminggu & -1.029 & 1.959 & .600 \\
& jarang & 1.771 & 2.309 & .444 \\
& setiap hari & $-3.003^{*}$ & 1.444 & $.038^{*}$ \\
4-6 kali seminggu & 1-3 kali seminggu & 1.029 & 1.959 & .600 \\
& jarang & 2.800 & 2.285 & .221 \\
& setiap hari & -1.974 & 1.406 & .161 \\
jarang & 1-3 kali seminggu & -1.771 & 2.309 & .444 \\
& 4-6 kali seminggu & -2.800 & 2.285 & .221 \\
\multirow{2}{*}{ setiap hari } & setiap hari & $-4.774^{*}$ & 1.862 & $.011^{*}$ \\
& 1-3 kali seminggu & $3.003^{*}$ & 1.444 & .038 \\
& 4-6 kali seminggu & 1.974 & 1.406 & .161 \\
\hline
\end{tabular}

Based on estimated marginal means

*. The mean difference is significant at the, 05 level.

b. Adjustment for multiple comparisons: Least Significant Difference (equivalent to no adjustments). 
Perbedaan Cyberbullying ditinjau dari Frekuensi Penggunaan Internet

Uji beda dilakukan dengan uji Anava 1 Jalur. Sesuai Tabel 6, uji beda analisis 1 jalur dapat diketahui terdapat perbedaan cyberbullying ditinjau dari frekuensi penggunaan internet $(\mathrm{F}=3,966$; $\operatorname{sig}<0,05)$.

Hasil pairwise (lihat Tabel 7) menunjukkan bahwa potensi perilaku cyberbullying terkait dengan frekuensi penggunaan internet berbeda secara signifikan ketika penggunaan internet adalah antara jarang dengan setiap hari $(\operatorname{sig}<0,05)$ dan antara 1-3 kali seminggu dengan setiap hari (sig < 0,05). Semakin sering individu menggunakan internet (setiap hari), maka semakin tinggi peluangnya untuk melakukan cyberbullying $(\mathrm{M}=6,473 ; \mathrm{SD}=$ 6,034).

\section{Perbedaan Cyberbullying ditinjau dari} Durasi Penggunaan Media Sosial

Uji beda dilakukan dengan uji Anava 1 Jalur. Berdasarkan tabel uji beda anava 1 jalur (lihat Tabel 8) dapat diketahui bahwa terdapat perbedaan cyberbullying ditinjau dari durasi penggunaan media sosial $(\mathrm{F}=12,910 ;$ sig $<0,05)$. Semakin lama individu menggunakan media sosial (lebih dari 4 jam), semakin tinggi peluang melakukan cyberbullying ( $\mathrm{M}=7,982 ; \mathrm{SD}$ $=7,012$ ).

Tabel 8. Perbedaan Cyberbullying ditinjau dari Durasi Penggunaan Media Sosial

\begin{tabular}{|c|c|c|c|c|c|}
\hline Durasi Penggunaan Medsos & Mean & \multicolumn{2}{|c|}{ Std. Deviation } & \multicolumn{2}{|c|}{$\mathrm{N}$} \\
\hline Kurang dari 1 jam & 3,400 & \multicolumn{2}{|c|}{3,952} & \multicolumn{2}{|c|}{20} \\
\hline $1-2$ jam & 4,161 & \multicolumn{2}{|c|}{4,424} & \multicolumn{2}{|c|}{68} \\
\hline 3-4 jam & 4,578 & \multicolumn{2}{|c|}{3,061} & \multicolumn{2}{|c|}{90} \\
\hline Lebih dari 4 jam & 7,982 & \multicolumn{2}{|c|}{7,012} & \multicolumn{2}{|c|}{169} \\
\hline Total & 6,087 & 5,867 & & & 47 \\
\hline Source & $\mathrm{df}$ & Mean Square & $\mathrm{F}$ & Sig. & $\begin{array}{c}\text { Partial Eta } \\
\text { Squared }\end{array}$ \\
\hline Durasi Penggunaan Medsos & 3 & 402,828 & 12,91 & $0,001 *$ & 0,101 \\
\hline Error & 343 & 31,204 & & & \\
\hline
\end{tabular}

Tabel 9. Hasil Pairwise Perbedaan Cyberbullying ditinjau dari Durasi Penggunaan Media Sosial

Dependent Variable: Cyberbullying

\begin{tabular}{llccc}
\hline (I) Penggunaan Medsos & (J) Penggunaan Medsos & M Diff. (I-J) & Std. Error & Sig. $^{\text {b }}$ \\
\hline 1-2 jam & 3-4 jam & -.416 & .898 & .643 \\
& kurang dari 1 jam & .762 & 1.421 & .592 \\
& lebih dari 4 jam & $-3.820^{*}$ & .802 & .000 \\
1-2 jam & .416 & .898 & .643 \\
3-4 jam & kurang dari 1 jam & 1.178 & 1.381 & .394 \\
& lebih dari 4 jam & $-3.404^{*}$ & .729 & .000 \\
kurang dari 1 jam & 1-2 jam & -.762 & 1.421 & .592 \\
& 3-4 jam & -1.178 & 1.381 & .394 \\
& lebih dari 4 jam & $-4.582^{*}$ & 1.321 & .001 \\
lebih dari 4 jam & 1-2 jam & $3.820^{*}$ & .802 & .000 \\
& 3-4 jam & $3.404^{*}$ & .729 & .000 \\
kased on estimated marginal means dari 1 jam & $4.582^{*}$ & 1.321 & .001 \\
\hline *. The mean difference is significant at the ,05 level. & & & \\
b. Adjustment for multiple comparisons: Least Significant Difference (equivalent to no adjustments).
\end{tabular}


Hasil pairwise (lihat Tabel 9) menunjukkan bahwa potensi perilaku cyberbullying terkait dengan durasi penggunaan media sosial berbeda secara signifikan ketika penggunaan media sosial adalah antara kurang dari 1 jam dengan lebih dari 4 jam $(\operatorname{sig}<0,05)$, antara $1-2$ jam dengan lebih dari 4 jam $(\operatorname{sig}<0,05)$, dan antara 3-4 jam dengan lebih dari 4 jam $(\operatorname{sig}<0,05)$.

\section{Pembahasan}

Hasil analisis menunjukkan bahwa disinhibisi online memiliki pengaruh mediasi antara kebingungan identitas dengan cyberbullying. Hasil penelitian ini selaras dengan Wright, Harper, dan Wasch (2019) yang melakukan sebuah penelitian yang berkaitan dengan persoalan perilaku cyberbullying dan disinhibisi online pada remaja dengan salah satu variabel yang berbeda yaitu trait. Hasil penelitian tersebut membuktikan bahwa ketika disinhibisi online menjadi mediator bagi hubungan antara trait dengan perilaku cyberbullying maka kekuatan hubungan tersebut akan semakin meningkat. Semakin tinggi anggapan seseorang akan adanya kebebasan bertindak ketika berada pada situasi anonim di dunia maya mampu membuat seseorang lebih terbebas dari risiko dan tanggung jawab atas tindakan yang dilakukannya. Ketika seseorang mela-kukan sebuah tindakan dan tidak dikenali sebagai orang yang melakukan tindakan tersebut dan merasa terbebas dari risiko dan tanggung jawab atas tindakannya di dunia maya, maka akan cenderung melakukan perilaku cyberbullying. Hasil yang sama juga ditemukan oleh Keipi dan Oksanen (2014).

Akan tetapi, hasil penelitian ini juga menunjukkan bahwa efek langsung dari kebingungan identitas lebih memberikan peranan terhadap cyberbullying dibandingkan efek tidak langsung melalui disinhibisi online. Hasil ini menjelaskan bahwa remaja yang mengalami kebi- ngungan identitas akan cenderung melakukan atau tidak melakukan tindakan yang membahayakan orang lain di dunia maya (cyber-bullying). Hasil penelitian sebelumnya menunjukkan bahwa semakin negatif penilaian remaja terhadap dirinya, maka semakin tinggi intensitas perilaku cyberbullying mereka lakukan $(\alpha<0,05)$ (Hidayaah \& Farizi, 2017).

Tahap kebingungan identitas dikenal sebagai identity versus identity confusion. Krisis yang terdapat dalam tahap tersebut bukan merupakan suatu bencana, tetapi merupakan suatu titik balik peningkatan kerentanan dan potensi, yang mempunyai kutub positif dan negatif (King, 2016). Remaja yang berada pada kondisi tersebut ditandai dengan karakteristik perilaku yang kacau dan perasaan rendah diri yang menyakitkan (Papalia, Olds, \& Feldman, 2009).

Apabila remaja dengan kebingungan identitas tidak mendapatkan penanganan dengan baik, maka akan memunculkan persoalan mental yang menjadi dasar bagi remaja untuk melakukan perilaku delinkuen seperti tidak toleran, menjadi kejam ketika mengucilkan orang lain, dan bahkan perilaku kriminal seperti perilaku cyberbullying (Erikson, 1968).

Hasil penelitian ini juga menunjukkan bahwa meskipun kondisi anonimitas menjadikan remaja menjadi terbebas dari konsekuensi sosial saat berada di dunia maya, namun pilihan melakukan perilaku cyberbullying lebih ditentukan oleh faktor mental dalam diri individu, sehingga dimungkinkan adanya faktor internal (bukan situasional) yang berperan dalam munculnya perilaku cyberbullying pada remaja.

Selanjutnya dilakukan uji tambahan dengan melihat perbedaan perilaku $c y$ berbullying ditinjau dari perbedaan jenis kelamin. Hasil menunjukkan bahwa tidak terdapat perbedaan pada perilaku cyberbullying antara laki-laki dan perempuan. Hasil deskriptif menunjukkan rata-rata skor perilaku cyberbullying perempuan lebih besar dari pada laki-laki. Hasil 
tersebut tidak sesuai dengan penelitian yang mengungkapkan bahwa laki-laki lebih sering melakukan perilaku cyberbullying dari pada perempuan $(\mathrm{Li}, 2007$; Hinduja \& Patchin, 2015; Ramdhani, 2016).

Namun menurut Patchin dan Hinduja (2012) perbedaan gender dalam perilaku cyberbullying sangat ditentukan oleh tipe atau bentuk cyberbullying yang dilakukan. Penelitian yang dilakukan Patchin dan Hinduja (2012), menunjukkan bahwa perempuan lebih sering melakukan perilaku cyber-bullying berupa mem-posting komentar atau tulisan yang menyakitkan, sedangkan laki-laki lebih sering melakukan perilaku cyberbullying dengan cara menyebarkan foto atau video yang memalukan.

Selain itu menurut King (2016), remaja perempuan dan laki-laki memiliki perbedaan karakteristik bentuk agresi. Remaja perempuan biasanya lebih sering terlibat dalam tidakan agresi secara relasional, yaitu perilaku agresif yang bertujuan untuk melukai status sosial orang lain seperti menyebarkan gosip sedangkan remaja laki-laki lebih sering terlibat dalam tindakan agresi secara fisik, seperti berkelahi. Oleh karena itu, perlu adanya penelitian lanjutan yang berfokus pada model perilaku cyberbullying pada remaja laki-laki dan perempuan, mengingat hasil penelitian ini menunjukkan remaja perempuan memiliki skor perilaku cyberbullying perempuan lebih besar dari pada laki-laki.

Hasil analisis tambahan yang lain, yaitu ditemukanya perbedaan perilaku cyberbullying dilihat dari frekuensi penggunaan internet. Semakin sering remaja menggunakan internet (setiap hari), semakin tinggi peluang melakukan cyberbullying. Peluang terjadinya perilaku cyberbullying ini terkait erat secara signifikan jika penggunaan internet dilakukan setiap hari. Hasil tersebut sesuai dengan penelitian yang dilakukan oleh Rice dkk., (2015) dimana ketika remaja menggunakan internet dengan durasi semakin tinggi, maka kecenderungan dalam melakukan perilaku cyberbullying juga semakin meningkat. Hasil analisis juga menunjukkan bahwa menggunakan internet 1-3 kali seminggu memiliki perbedaan signifikan dengan remaja yang menggunakan setiap hari. Sehingga, 3 kali seminggu adalah batas maksimal yang bisa diberikan oleh remaja terkait dengan penggunaan internet.

Selain itu, juga ditemukan perbedaan perilaku cyberbullying dilihat dari durasi penggunaan media sosial pada remaja. Semakin lama remaja menggunakan media sosial dalam sehari, maka semakin meningkat jumlah rata-rata remaja melakukan cyberbullying. Semakin sering individu menggunakan media sosial (lebih dari 4 jam), semakin tinggi peluang melakukan cyberbullying. Hal ini sesuai dengan penelitian Guard Child (2017) dimana remaja yang menghabiskan waktu lebih dari 3 jam per harinya cenderung lebih mungkin terlibat dalam permasalahan cyberbullying. Batas waktu maksimal ini agak berbeda dengan temuan hasil analisis tambahan dalam penelitian ini. Berdasarkan hasil analisis tambahan, ditemukan bahwa potensi perilaku cyberbullying terkait dengan durasi penggunaan media sosial berbeda secara signifikan ketika penggunaan media sosial adalah antara kurang dari 1 jam dengan lebih dari 4 jam, antara 1-2 jam dengan lebih dari 4 jam, dan antara 3-4 jam dengan lebih dari 4 jam. Sehingga, batas maksimal durasi penggunaan media sosial berdasarkan hasil analisis penelitian ini adalah empat jam.

Berdasarkan hasil analisis, dapat dikalkulasikan sebanyak $74 \%$ remaja menggunakan media sosial lebih dari 3 jam perharinya dan $87 \%$ menggunakan internet setiap hari. Hal tersebut menunjukan bahwa penggunaan media sosial pada remaja sangatlah tinggi dan melebihi rata-rata penggunaan media sosial se-Indonesia dengan kurun waktu 3 sampai 3,23 jam perhari (We are Social, 2018). Remaja adalah individu yang 
belum matang secara emosional dan masih membutuhkan pengawasan serta bimbingan dalam penggunaan intenet dan media sosial (Herdiana, 2018). Oleh karena itu, aktivitas penggunaan internet pada remaja khususnya media sosial kiranya harus menjadi perhatian bagi orang tua.

Kelemahan penelitian ini adalah belum optimalnya peran mediator dibandingkan efek langsung. Hal ini menunjukkan bahwa banyak faktor yang berperan dalam menjelaskan perilaku cyberbullying remaja.

\section{Simpulan}

Berdasarkan tujuan dan pembahasan pada penelitian ini, maka dapat disimpulkan bahwa ada pengaruh mediasi disinhibisi online pada hubungan antara kebingungan identitas dengan cyberbullying. Akan tetapi, efek kebingungan identitas memiliki peranan yang lebih besar dalam model ini.

\section{Saran}

Berdasarkan kesimpulan tersebut, maka peneliti dapat memberikan saran yang dapat menjadi pertimbangan bagi persoalan perilaku cyberbullying pada remaja. Bagi remaja hendaknya perlu merumuskan pemahaman diri dan peranan di lingkungan sosial sehingga dapat menjadi pribadi yang bertanggungjawab dan tidak terlibat dalam perilaku cyberbullying.

Bagi orang tua dan tenaga pendidik sebaiknya membantu remaja dalam merumuskan pemahaman diri dan peran di lingkungan sosialnya sehingga dapat membantu mereka dalam melatih diri untuk bertanggungjawab atas tindakan yang dilakukannya saat berada di dunia maya.

Bagi penelitian selanjutnya, disarankan melakukan penelitian menggunakan pendekatan eksperimental untuk menguji efek kebingungan identitas terhadap cyberbullying dan melakukan kontrol pada disinhibisi online.

\section{Daftar Pustaka}

Baron, R. M., \& Kenny, D. A. (1986). The moderator-mediator variable distinction in social psychological research: conceptual, strategic, and statistical considerations. Journal of Personality and Social Psychology, 51(6), 1173-1182. https://doi.org/10.1037//00223514.51.6.1173

Chadwick, S. (2014). Impacts of Cyberbullying, Building Social and Emotional Resilience in School. New York: Springer.

Ching, T., Wu, L. S., \& Shih, J.-F. (2017). Examining the Antecendents of Online Disinhibition. Emerald Insight: Information Technology \& People, $\quad 30(1), \quad 1-26$.

\section{https://doi.org/10.1108/ITP-07-} 2015-0167

Dayton, T. (2011). Creating a false self: Learning to live a lie [Web log post]. Retrieved from https://www.huffingtonpost.com/drtian-dayton/creating-a-false selflea_b_269096.html

Erikson, E. H. (1968). Identity Youth and Crisis. Ney York: W. W. Norton.

Gayatri, G., Rusadi, U., Meiningsih, S., Mahmudah, D.,Sari, D., Kautsarina, Karman, \& Nugroho, A. C. (2015). Perlindungan Pengguna Media Digital di Kalangan Anak dan Remaja di Indonesia. Jurnal Penelitian dan Pengembangan Komunikasi dan Informatika, 6(1), 116. Retrieved from 
http://digilib.mercubuana.ac.id/mana ger/t! @file_artikel_abstrak/Isi_Artik el_257476942796.pdf

Gil-Or, O., Levi-Belz, Y., \& Turel, O. (2015). The "Facebook-self": characteristics and psychological predictors of false self-presentation on Facebook. Frontiers in Psychology, 6(99), 1-10. https://doi.org/10.3389/fpsyg.2015.0 0099

Görzig, A., \& Ólafsson, K. (2014). What Makes a Bully a Cyberbully? Unravelling the Characteristics of Cyberbullies across Twenty-Five European Countries. Journal of Children and Media , 7 (1), 8-25. https://doi.org/10.1080/17482798.20 12.739756

Guard Child. (2017). Cyber Bullying Statistics. Retrieved from https://www.guardchild.com/cyberbullying-statistics/

Herdiana, I. (2018). Media Sosial dan Human Trafficking: Sebuah Ulasan. In H. P. Indonesia, Psikologi dan Teknologi Informasi (pp. 127-144). Jakarta: Himpunan Psikologi Indonesia.

Hidayaah, N., \& Farizi, A. M. (2017). Relationship Between Self-Concept and the Intensity of Cyberbullying in Class XI of Dharma Wanita Senior High School Surabaya. Proceeding Surabaya International Health Conference, 1(1), 435-439. http://journal.unusa.ac.id/index.php/ sihc/article/view/349/314

Hinduja, S., \& Patchin, J. W. (2015). Bullying Beyond Schoolyard: Preventing and Responding to Cyberbullying Second Edition. Thousand Oaks, CA: Sage Publication.

Hu, C., Kumar, S., Huang, J., \& Ratnavelu, K. (2017). Disinhibition of negative true self for identity reconstructions in cyberspace: Advancing self-discrepancy theory for virtual setting. Plos One , 12(4), 1-19.

https://doi.org/10.1371/journal.pone. 0175623

IPSOS. (2011). One in Ten (12\%) Parents Online, Around the World Say Their Child Has Been Cyberbullied, 26\% Say They Know of a Child Who Has Experienced Same in Their Community. Retrieved from https://www.ipsos.com/en-us/newspolls/one-ten-12-parents-onlinearound-world-say-their-child-hasbeen-cyberbullied-26-say-theyknow-child

Keipi, T., \& Oksanen, A. (2014). Selfexploration, Anonymity and Risks in the Online Setting: Analysis of Narratives by 14-18-Year Olds. Journal of Youth, 17(8), 1097-1113. https://doi.org/10.1080/13676261.20 14.881988

King, L. (2016). Psikologi Umum: Sebuah Pandangan Apresiatif (Edisi 3 Buku 1). Jakarta: Salemba Humanika.

Li, Q. (2007). New Bottle but Old Wine: a Research of Cyberbullying in Schools. Computers in Human Behavior, 23 (4), 1777-1791. https://doi.org/10.1016/j.chb.2005.1 0.005

Morissan. (2012). Metode Penelitian Survei. Jakarta: Kencana.

Papalia, D. E., Olds, S. W., \& Feldman, R. D. (2009). Human Development Perkembangan Manusia (Edisi 10, Buku 2). Jakarta: Salemba Humanika.

Patchin, J. W., \& Hinduja, S. (2010). Cyberbullying and Self-Esteem. Journal of School Health , 80(12), 614-621. https://doi.org/10.1111/j.17461561.2010.00548.x 
Patchin, J. W., \& Hinduja, S. (2012). Cyberbullying Prevention and Response Expert Perspective. New York: Routlege Taylor and Francis.

Ramdhani, N. (2016). Emosi Moral dan Empati pada Pelaku Perundungansiber. Jurnal Psikologi, 43(1),66-80. https://doi.org/10.22146/jpsi.12955

Rice, E., Petering, R., Rhoades, H., Winetrobe, H., Goldbach, J., Plant, A., et al. (2015). Cyberbullying Perpetration and Victimization Among. American Journal of Public Health , 105 (3), 66-72. https://doi.org/10.2105/AJPH.2014. 302393

Schwartz, S. J., Zamboanga, B. L., Weisskirch, R. S., \& Rodriguez, L. (2009). The relationships of personal and ethnic identity exploration to indices of adaptive and maladaptive psychosocial functioning. International Journal of Behavioural Development, 33(2), 131-144. https://doi.org/10.1177/0165025408 098018

The Jakarta Post. (2016). Most Youth Unaware of Cyberbullying. Retrieved September 3, 2016, from https://www.thejakartapost.com/new s/2016/09/03/most-youth-unawarecyberbullying.html

Udris, R. (2014). Cyberbullying Among High School Student in Japan:
Development and Validation of the Online Disinhibition Scale. Computers in Human Behavior , 41, 253-261.

https://doi.org/10.1016/j.chb.2014.0 9.036

Udris, R. (2017). Psychological and Social Factor as Predictors of Online and Offline Deviant Behavior Among Japanese Adolescent. Deviant Behavior, 38(7), 1-18. https://doi.org/10.1080/01639625.20 16.1197689

We are Social. (2018, January 30). DigitalL in 2018: World's Internet Users Pass The 4 Billion Mark. Retrieved March 05, 2018, from https://wearesocial.com/blog/2018/0 1/global-digital-report-2018

Widhiarso, W. (2012). Beberapa Ukuran Efek dalam Analisis Regresi Mediator. Retrieved from https://www.researchgate.net/public ation/340137117_Beberapa_Ukuran _Efek_dalam_Analisis_Regresi_den gan_Mediator

Wright, M. F., Harper, B. D., \& Wachs, S. (2019). The Association Between Cyberbullying and Callousunemotional Traits Among Adolescents: The Moderating Effect of Online Disinhibition. Personality and Individual Difference, 140, 4145.https://doi.org/10.1016/j.paid.201 8.04 .001 